\title{
Nucleotide Pyrophosphatase/Phosphodiesterase 1 Is Responsible for Degradation of Antisense Phosphorothioate Oligonucleotides
}

\author{
MARZENA WÓJCIK,,${ }^{1}$ MARCIN CIEŚLAK,,${ }^{1}$ WOJCIECH J. STEC,${ }^{1}$ JAMES W. GODING, ${ }^{2}$ \\ and MARIA KOZIOŁKIEWICZ ${ }^{1,3}$
}

\begin{abstract}
The rapid degradation of unmodified phosphodiester oligodeoxynucleotides (PO-oligos) by exo- and endonucleases limits their application as antisense constructs and requires the synthesis and use of modified oligonucleotides. Phosphorothioate analogs of oligonucleotides (PS-oligos) are much more stable against nucleolytic degradation than their unmodified counterparts, and this is one of the reasons for which they are a promising class of antisense oligonucleotides. However, PS-oligos also undergo slow hydrolysis by enzymes present in plasma. The oligonucleotide degradation proceeds mainly from the $3^{\prime}$-end, resulting in the formation of a typical ladder of shorter products and the release of the mononucleoside $5^{\prime}$-phosphorothioates.

So far, little has been known concerning the molecular identity of the enzymes involved in the degradation of PS-oligos. We now identify the human plasma 3 '-exonuclease responsible for their degradation as a soluble form of nucleotide pyrophosphatase/phosphodiesterase 1 (NPP1) (EC 3.1.4.1/EC 3.6.1.9), also known as the plasma cell differentiation antigen PC-1. We also show that adenosine or deoxyadenosine ( $\alpha$-thio)triphosphates can act as potent inhibitors of NPPs.
\end{abstract}

\section{INTRODUCTION}

$\mathbf{I}_{\mathrm{c}}^{\mathrm{T}}$ IS WELL KNOWN that unmodified oligodeoxynucleotides (PO-oligos) are rapidly degraded by exonucleases and endonucleases present in tissues and blood (Wickstrom, 1986), which limits their application as antisense constructs in vivo. A number of different types of modified oligonucleotides have been synthesized and one of them are phosphorothioate oligonucleotides (PSoligos) containing a sulfur atom attached to phosphorus at each internucleoside bond (Guga et al., 1998). Although PS-oligos are much more resistant to nucleolytic enzymes than the PO-oligos, they have been shown to be degraded in blood, plasma and various cellular systems
(Dias and Stein, 2002). Taking into account that both unmodified and phosphorothioate oligonucleotides are degraded successively from the $3^{\prime}$-end to the $5^{\prime}$-end with the formation of a typical ladder of products and release of nucleoside-5'-phosphates or 5' -phosphorothioates, the enzyme(s) responsible for this type of degradation have been termed 3'-exonuclease(s) (Eder et al., 1991).

Although metabolism and pharmacokinetics of PS-oligos have been studied in detail (Graham et al., 1998; Levin, 1999; Crooke et al., 2000), until now the molecular nature and substrate specificity of these enzyme(s) have not been determined. The enzyme(s) responsible for metabolism of antisense oligonucleotides are present not only in plasma but also mainly in solid tissues, where the

\footnotetext{
${ }^{1}$ Department of Bioorganic Chemistry, Centre of Molecular and Macromolecular Studies, Polish Academy of Sciences, Lódź, Poland.

${ }^{2}$ Department of Pathology and Immunology, Monash University, Prahran, Victoria, Australia.

${ }^{3}$ Department of Technical Biochemistry, Technical University of Lódź, 90-924 kódź, Poland.
} 
oligonucleotides are distributed as the result of rapid plasma clearance (Levin, 1999). Degradation of these oligomers not only decreases their effective concentration but also generates mononucleoside $5^{\prime}$-phosphates or 5 '-phosphorothioates which may influence cell proliferation (Vaerman et al., 1997; Koziolkiewicz et al., 2001). For these reasons the pharmacokinetic behavior of antisense oligonucleotides in different organs or different cell compartments has been difficult to predict.

In our earlier studies, we found that the 3 '-exonuclease present in human plasma is $R_{\mathrm{P}}$-selective, that is, it cleaves internucleotide phosphorothioate linkages of the $\left[\mathrm{R}_{\mathrm{P}}\right]$-configuration and not those of the $\left[\mathrm{S}_{\mathrm{P}}\right]$-configuration (Koziolkiewicz et al., 1997; Gilar et al., 1998). We have also shown that hydrolysis of PS-oligos catalyzed by human plasma 3'-exonuclease proceeds with participation of a covalent enzyme-substrate intermediate (Koziolkiewicz et al., 2002). A similar two-step mechanism that includes formation of a covalent substrate-enzyme intermediate has also been proposed for nucleotide pyrophosphatases/phosphodiesterases (NPP) (Gijsbers et al., 2001).

Taking into account the stereochemical mechanism of the $3^{\prime}$-exonuclease action and inhibitory effects caused by nucleoside triphosphates and their analogs, we have formulated a hypothesis that the $3^{\prime}$-exonucleolytic activity of human plasma can be attributed to a NPP. We now provide evidence that nucleotide pyrophosphatase/phosphodiesterase 1 (NPP1), also known as the plasma cell differentiation antigen PC-1, is responsible for degradation of unmodified oligonucleotides and their phosphorothioate analogs. We have also shown that phosphorothioate analogs of mononucleotides can inhibit the enzymatic activity of the NPP.

\section{MATERIALS AND METHODS}

All reagents were of analytical grade. T4 polynucleotide kinase (EC 2.7.1.78) was obtained from Amersham. Heparin, pyridoxal phosphate-6-azophenyl-2',4'-disulfonic acid (PPADS), diadenosine tetraphosphate $\left(\mathrm{Ap}_{4} \mathrm{~A}\right)$, adenosine triphosphate (ATP), adenosine $5^{\prime}$ - $(\gamma$-thio)triphosphate $(\mathrm{ATP} \gamma \mathrm{S})$, UDP-glucose, $p$-nitrophenyl-thymidine monophosphate ( $p$-nitrophenyl-TMP), and lysophosphatidylcholine (oleoyl 18:0) (LPC) were purchased from Sigma-Aldrich. GammaBind Plus Sepharose and Protein G Sepharose 4 Fast Flow suspension were from Pharmacia Biotech AB. Adenosine $5^{\prime}-(\alpha$-thio)triphosphate (ATP(S) and cytidine $5^{\prime}-(\alpha$-thio)triphosphate $(\mathrm{CTP} \alpha \mathrm{S})$ were obtained as the $S_{P}$ isomers after enzymatic phosphorylation of AMPS and CMPS by adenylate and pyruvate kinases (Connolly et al., 1984; Koziolkiewicz et al., 2002). Deoxyadenosine $5^{\prime}$ - $(\alpha$-thio)triphosphate $(\mathrm{dATP} \alpha \mathrm{S})$ was synthesized as a mixture of diastereomers (Misiura et al., 2005), which were separated using high-performance liq- uid chromatography (HPLC; an ODS Hypersil column, $4.6 \times 260 \mathrm{~mm})$ using a linear gradient of $0-10 \%$ $\mathrm{CH}_{3} \mathrm{CN} / 0.1 \mathrm{M}$ triethyl ammonium bicarbonate (TEAB) $\mathrm{pH} 7.4,0.33 \% / \mathrm{minute}$ at a flow rate $1 \mathrm{~mL} / \mathrm{min}$. The retention times for the $S_{P}$ and $R_{P}$ isomers were 20.85 and 21.85 minutes, respectively. Deoxynucleoside 5'-phosphorothioates dNMPS (where $n=\mathrm{A}, \mathrm{G}, \mathrm{C}$ or T) were synthesized using the modified method of Murray and Atkinson (1968) and purified by HPLC.

\section{Plasma}

Plasma was isolated from human blood containing $0.38 \%$ sodium citrate by centrifugation at $16,000 \times g$ for 5 minutes. Plasma aliquots were carefully withdrawn, leaving the packed cells untouched.

\section{Synthesis of oligonucleotides}

Unmodified oligonucleotides (1-2, 7-8) were prepared by the phosphoramidite method on an ABI 391 synthesizer. PS-oligos $(3-4,6)$ were synthesized using the oxathiaphospholane method as described elsewhere (Stec et al., 1995). The oligonucleotides 3 and 6 contain exclusively $\mathrm{R}_{\mathrm{P}}$-internucleotide bonds, whereas the oligomer 4 contains 10 consecutive $R_{P}$ bonds followed by a single $S_{P}$ linkage located at the $3^{\prime}$ end. The diastereomeric purity of the oligonucleotides 3,4 , and 6 was previously confirmed by enzymatic degradation using $\mathrm{R}_{\mathrm{P}^{-}}$and $\mathrm{S}_{\mathrm{P}^{-}}$-specific enzymes: snake venom phosphodiesterase and nuclease P1, respectively (Stec et al., 1995). Chimeric PO/PS-oligo $(5,9,10,11)$ were synthesized by the phosphoramidite method with sulfurization of internucleotide phosphites by means of bis(O,O-diisopropoxy phosphinothioyl)disulfide (S-Tetra) (Stec et al., 1993). The oligonucleotide 9 was synthesized and used in degradation studies as mixture of diastereomers, whereas oligonucleotides 10 and 11 were obtained by reversedphase (RP)-HPLC separation of the former oligonucleotide 9 (ODS Hypersil column) using a linear gradient of 0-40\% $\mathrm{CH}_{3} \mathrm{CN} / 0.1 \mathrm{M}$ TEAB pH 7.4, 0.35\%/minute at a flow-rate of $1 \mathrm{~mL} / \mathrm{min}$. A phosphorothioate hexamer PS$\mathrm{d}[\mathrm{A}]_{6}(12)$ containing at the $3^{\prime}$ end two consecutive internucleotide bonds of $\mathrm{R}_{\mathrm{P}}$ configuration and labeled in the nonbridging positions with $\left[{ }^{18} \mathrm{O}\right]$ oxygen was synthesized via the oxathiaphospholane method as described previously (Guga et al., 2001). Purification of all oligonucleotide constructs 1-12 was carried out by RP-HPLC (Zon and Stec, 1991), and their purity was confirmed by $20 \%$ polyacrylamide gel electrophoresis (PAGE).

\section{Oligonucleotide labeling}

The oligonucleotides used in these studies were $5^{\prime}$-end labeled with $\left[\gamma_{-}{ }^{32} \mathrm{P}\right] \mathrm{ATP}$ and T4 polynucleotide kinase. A mixture $(20 \mu \mathrm{L})$ containing $10 \mathrm{mM}$ Tris- $\mathrm{Cl} \mathrm{pH} 8.5,10$ 
Table 1. Oligonucleotide Constructs Used in the 3'-Exonuclease Studies

\begin{tabular}{lll}
\hline No. & \multicolumn{1}{c}{ Oligonucleotide sequence $5^{\prime} \rightarrow 3^{\prime}$} & \multicolumn{1}{c}{ Type of internucleotide bonds } \\
\hline 1 & {$[\mathrm{PO}]-\mathrm{d}\left[\mathrm{T}_{12}\right]$} & Phosphodiester \\
2 & {$[\mathrm{PO}]-\mathrm{d}\left[\mathrm{A}_{12}\right]$} & Phosphodiester \\
3 & {$\left[\mathrm{R}_{\mathrm{P}}-\mathrm{PS}\right]-\mathrm{d}\left[\mathrm{T}_{12}\right]$} & Phosphorothioate \\
4 & {$\left[\mathrm{R}_{\mathrm{P}}\right.$-but last one-PS]-d $\left[\mathrm{T}_{12}\right]$} & Phosphorothioate \\
5 & {$[\mathrm{PO} / \mathrm{Mix}-\mathrm{PS}]-\mathrm{d}\left[\mathrm{T}_{\mathrm{PO}} \mathrm{T}_{\mathrm{PO}} \mathrm{T}_{\mathrm{PO}} \mathrm{T}_{\mathrm{PO}} \mathrm{T}_{\mathrm{PO}} \mathrm{T}_{\mathrm{PO}} \mathrm{T}_{\mathrm{PO}} \mathrm{T}_{\mathrm{PO}} \mathrm{T}_{\mathrm{PO}} \mathrm{T}_{\mathrm{PO}} \mathrm{T}_{\mathrm{PS}} \mathrm{T}\right]$} & Phosphodiester/phosphorothioate \\
6 & {$\left[\mathrm{R}_{\mathrm{P}}-\mathrm{PS}\right]-\mathrm{d}\left[\mathrm{A}_{12}\right]$} & Phosphorothioate \\
7 & {$[\mathrm{PO}]-\mathrm{d}[\mathrm{TCCTCTTTTTTT}]$} & Phosphodiester \\
8 & {$[\mathrm{PO}]-\mathrm{d}[\mathrm{TCTTTTTC}]$} & Phosphodiester \\
9 & {$[\mathrm{PO} / \mathrm{Mix}-\mathrm{PS}]-\mathrm{d}\left[\mathrm{T}_{\mathrm{PO}} \mathrm{C}_{\mathrm{PO}} \mathrm{T}_{\mathrm{PO}} \mathrm{T}_{\mathrm{PO}} \mathrm{T}_{\mathrm{PO}} \mathrm{T}_{\mathrm{PO}} \mathrm{T}_{\mathrm{PS}} \mathrm{C}\right]$} & Phosphodiester/phosphorothioate \\
10 & {$\left[\mathrm{PO} / \mathrm{R}_{\mathrm{P}}-\mathrm{PS}\right]-\mathrm{d}\left[\mathrm{T}_{\mathrm{PO}} \mathrm{C}_{\mathrm{PO}} \mathrm{T}_{\mathrm{PO}} \mathrm{T}_{\mathrm{PO}} \mathrm{T}_{\mathrm{PO}} \mathrm{T}_{\mathrm{PO}} \mathrm{T}_{\mathrm{PS}} \mathrm{C}\right]$} & Phosphodiester/phosphorothioate \\
11 & {$\left[\mathrm{PO} / \mathrm{S}_{\mathrm{P}}-\mathrm{PS}\right]-\mathrm{d}\left[\mathrm{T}_{\mathrm{PO}} \mathrm{C}_{\mathrm{PO}} \mathrm{T}_{\mathrm{PO}} \mathrm{T}_{\mathrm{PO}} \mathrm{T}_{\mathrm{PO}} \mathrm{T}_{\mathrm{PO}} \mathrm{T}_{\mathrm{PS}} \mathrm{C}\right]$} & Phosphodiester/phosphorothioate \\
12 & {$[\mathrm{PS}]-\mathrm{d}\left[\mathrm{A}_{6}\right]$} & Phosphorothioate \\
\hline
\end{tabular}

$\mathrm{mM} \mathrm{MgCl} 2,7 \mathrm{mM} \beta$-mercaptoethanol, 25-50 $\mu \mathrm{M}$ oligonucleotide $\left(0.5-1.0 \mathrm{nmol}, 0.1 \mathrm{~A}_{260}\right.$ unit), $1 \mu \mathrm{L}(10 \mu \mathrm{Ci})$ $\left[\gamma_{-}{ }^{32} \mathrm{P}\right] \mathrm{ATP}$, and $\mathrm{T} 4$ polynucleotide kinase (5 units) was incubated for 3 hours at $37^{\circ} \mathrm{C}$, then heat denatured and stored at $-20^{\circ} \mathrm{C}$. The purity of the oligonucleotides was controlled by running ${ }^{32} \mathrm{P}$-labeled samples on a $20 \%$ polyacrylamide and $7 \mathrm{M}$ urea gel, followed by densitometric analysis of the autoradiograms.

\section{Assay for nucleolytic activity of human plasma}

The aliquots of ${ }^{32} \mathrm{P}$-labeled oligonucleotides $(0.25-0.5$ nmol) were incubated in human plasma diluted immediately before the experiment to $50 \%$ by addition of an equal volume of phosphate-buffered saline (PBS; total volume of $50 \mu \mathrm{L}$ ) at $37^{\circ} \mathrm{C}$. At various times (usually 0,1 , 2,4 , and 8 hours), $10-\mu \mathrm{L}$ aliquots were withdrawn, and the enzymatic reaction was quenched by heating for 2 minutes at $95^{\circ} \mathrm{C}$. Then, $50 \mu \mathrm{L}$ of water was added to each denatured sample. After vigorous shaking, the protein precipitates were spun down, and the aqueous solutions were dried in a Speed Vac rotary evaporator. The resultant samples were dissolved in formamide containing $0.03 \%$ Bromophenol Blue and $0.03 \%$ xylene cyanol (5-8 $\mu \mathrm{L}$ ) and analyzed by $20 \%$ polyacrylamide and $7 \mathrm{M}$ urea gel electophoresis. The autoradiograms were scanned using an LKB XL densitometer or Molecular Dynamics Phosphorimager.

Kinetic analyses of the nucleolytic activity of human plasma were carried out as described above but with varied concentrations of the oligonucleotides 1-3 (Tables 1 and 2). Oligomer 1 was incubated in 50\% human plasma for 10 minutes, while substrates 2 and 3 were incubated for 60 minutes. In all cases, the initial rates were calculated from reactions in which the substrates were converted in less than $20 \%$. The $\mathrm{V}_{\max }$ and $\mathrm{K}_{\mathrm{m}}$ values were de-

Table 2. Kinetic Parameters Determined for PO- and PS-Oligo Used in These Studies

\begin{tabular}{|c|c|c|c|c|}
\hline No. & $\begin{array}{l}\text { Oligonucleotide } \\
\qquad 5^{\prime} \rightarrow 3^{\prime}\end{array}$ & $K_{m}$ value $(\mu M)$ & $\begin{array}{c}V_{\max } \\
(\mu M / \text { minute })\end{array}$ & $\begin{array}{c}t_{1 / 2} \\
\text { (hours) }\end{array}$ \\
\hline 1 & {$[\mathrm{PO}]-\mathrm{d}\left[\mathrm{T}_{12}\right]$} & 16 & 1.0 & 0.3 \\
\hline 2 & {$[\mathrm{PO}]-\mathrm{d}\left[\mathrm{A}_{12}\right]$} & 71.5 & 2.4 & 2 \\
\hline 3 & {$\left[\mathrm{R}_{\mathrm{P}}-\mathrm{PS}\right]-\mathrm{d}\left[\mathrm{T}_{12}\right]$} & 173 & 2.0 & 4 \\
\hline 4 & {$\left[\mathrm{R}_{\mathrm{P}}\right.$-but last one-PS $]-\mathrm{d}\left[\mathrm{T}_{12}\right]$} & Not hydrolyzed & Not hydrolyzed & $\mathrm{S}$ \\
\hline
\end{tabular}

$\mathrm{S}=$ stable after 8 hours of incubation, after this time no products of degradation were identified. Oligonucleotides 1-3 were incubated in 50\% human plasma for 10 minutes (the oligomer 1) or for 60 minutes (the substrates 2 and 3). Initial rates were calculated from reactions in which no more than $20 \%$ of the substrates were converted into products. $\mathrm{V}_{\max }$ and $\mathrm{K}_{\mathrm{m}}$ values were determined in a wide range of the substrates concentrations ( $0-50 \mu \mathrm{M}$ for the oligomer 1 ; $0-120 \mu \mathrm{M}$ for the oligomer 2 and $0-240 \mathrm{M}$ for the oligomer 3) from the $y$ intercept and slope, respectively, of the best-fit line to a Lineweaver-Burke plot of $1 / V$ versus $1 /[\mathrm{S}]$. In all cases, good fits to the appropriate kinetic model were obtained, with 7-8 experimental points and correlation coefficient $R^{2}>0.96$. The $\mathrm{t}_{1 / 2}$ was determined at a total oligomer concentration of $5 \mu \mathrm{M}$. 
termined from the $y$ intercept and the slope values, respectively, which were obtained from numerical fitting of a Lineweaver-Burke plot of $1 / V$ versus $1 /[\mathrm{S}]$.

\section{Inhibitors}

The following compounds were analyzed as potential inhibitors of oligonucleotide hydrolysis: dAMPS (5-50 $\mu \mathrm{M})$, dCMPS $(5-50 \mu \mathrm{M})$, dGMPS $(5-50 \mu \mathrm{M})$, TMPS (5-50 $\mu \mathrm{M}), \operatorname{ATP} \alpha \mathrm{S}(1-100 \mu \mathrm{M}), \operatorname{ATP} \gamma \mathrm{S}(1-100 \mu \mathrm{M})$, CTP $\alpha \mathrm{S} \quad(1-100 \mu \mathrm{M}), \mathrm{R}_{\mathrm{P}}-\mathrm{dATP} \alpha \mathrm{S}$ and $\mathrm{S}_{\mathrm{P}}-\mathrm{dATP} \alpha \mathrm{S}$ (0.05-20 $\mu \mathrm{M}), p$-nitrophenyl-TMP $(2-100 \mu \mathrm{M})$, PPADS $(5-100 \mu \mathrm{M}), \mathrm{Ap}_{4} \mathrm{~A}(10-100 \mu \mathrm{M})$, heparin $(0.5-15$ $\mathrm{mg} / \mathrm{mL})$, UDP-glucose $(80-800 \mu \mathrm{M})$, and lysophosphatidylcholine $(80-800 \mu \mathrm{M})$. Different concentrations of the inhibitors were added to 50\% human plasma, and the resultant mixtures were preincubated for $5 \mathrm{~min}$ at $37^{\circ} \mathrm{C}$. Then, one of the oligonucleotides 2,6 , or 7 was added to these mixtures to obtain finally its $5 \mu \mathrm{M}$ concentration and incubation of the samples was prolonged to 2 and 6 hours for the oligonucleotide 7 and 2, respectively. The phosphorothioate oligomer 6 was incubated for 16 hours. The different incubation times reflect different susceptibility of the oligonucleotides 2, 6, and 7 to the enzymatic degradation. Products of the oligonucleotide degradation were recovered from the incubation mixtures and analyzed as described above. Their densitometric analysis allowed to calculate the level of $5^{\prime}$ mononucleotides released as the final products during the incubation time. The $\mathrm{IC}_{50}$ values (presented in Tables 4 and 5 below) were determined as an inhibitor concentration necessary to decrease the release of the $5^{\prime}$-mononucleotides by $50 \%$.

\section{Immunoprecipitation of $\mathrm{PC}-1$ protein (NPP1) from human serum}

Human serum $(0.75 \mathrm{~mL})$ diluted with PBS to a total volume of $1.5 \mathrm{~mL}$ was passed through a syringe filter $(0.4 \mu \mathrm{m})$ and then was passed through an affinity column containing $3.5 \mathrm{~mL}$ of GammaBind Plus Sepharose (Pharmacia Biotech $A B$ ) to remove immunglobulin $G(\operatorname{IgG})$. Unbound proteins were eluted with PBS and collected as $500-\mu \mathrm{L}$ fractions (a total of 20 fractions were collected). Fractions containing serum proteins were identified by measurement of ultraviolet (UV) absorption at $280 \mathrm{~nm}$ and combined. The column was then regenerated with $0.05 \mathrm{M}$ glycine- $\mathrm{HCl}$ buffer $\mathrm{pH} 2.7$ (removal of $\mathrm{IgG}$ ) followed by equilibration with PBS. To assure that all IgG molecules were removed, combined fractions of serum proteins were passed again through a GammaBind Plus Sepharose column and eluted with PBS. Fractions containing serum proteins were combined and used for immunoprecipitation. The column was then regenerated with $0.05 \mathrm{M}$ glycine- $\mathrm{HCl}$ buffer $\mathrm{pH} 2.7$.

IgG-depleted serum $(600 \mu \mathrm{L})$ was incubated with $1 \mu \mathrm{g}$ of 3E8 monoclonal antibodies or $1 \mu \mathrm{g}$ of HOPC- 1 antibodies (used as a negative control) for 5 hours at $4^{\circ} \mathrm{C}$ on a wheel mixer. Then $50 \mu \mathrm{L}$ of $50 \%$ Protein G Sepharose 4 Fast Flow suspension (Amersham Pharmacia Biotech AB) was added to each sample and gently mixed for 1 hour at $4^{\circ} \mathrm{C}$ on a wheel mixer. The Sepharose beads were then spun down (at 12,000 $\times g$ for 20 seconds at room temperature) and washed four times with $500 \mu \mathrm{L}$ of 50 $\mathrm{mM}$ Tris- $\mathrm{HCl}$ buffer $\mathrm{pH} 8.0$ with $1 \mathrm{mM} \mathrm{MgCl}$. Finally, Protein G Sepharose immunoprecipitates were suspended in $30 \mu \mathrm{L}$ of $50 \mathrm{mM}$ Tris- $\mathrm{HCl}$ buffer $\mathrm{pH} 8.0$ with $1 \mathrm{mM} \mathrm{MgCl}{ }_{2}$ and used to assay the $3^{\prime}$-exonuclease activity.

For this purpose 0.1 OD of ${ }^{32} \mathrm{P}-5^{\prime}$-end-labeled [PO]$\mathrm{d}\left[\mathrm{T}_{12}\right]$ (1) was added to $3 \mathrm{E} 8$ or HOPC-1 immunoprecipitates and, independently, to Protein G Sepharose 4 Fast Flow alone, mixed, and incubated at $37^{\circ} \mathrm{C}$. After $0.5,1$, 2 , and 4 hours of incubation, $5-\mu \mathrm{L}$ samples were taken out, denatured at $90^{\circ} \mathrm{C}$ for 3 minutes, and frozen $\left(-20^{\circ} \mathrm{C}\right)$. A similar procedure was used for $\left[\mathrm{R}_{\mathrm{p}}-\mathrm{PS}\right]-$ $\mathrm{d}\left[\mathrm{T}_{12}\right]$ (3) as a substrate, except for different incubation times $(0,4,8$, and 24 hours) and the fact that the oligomer 3 was unlabeled. The ${ }^{32} \mathrm{P}-5^{\prime}$-end-labeling (with T4 PNK and $\left.\left[\gamma^{-32} \mathrm{P}\right] \mathrm{ATP}\right)$ of the oligomer and its exonucleolytic degradation products followed the denaturation step. After electrophoretic analysis carried out as described above, the gels obtained were analyzed with Molecular Dynamics Phosphoimager.

The supernatants obtained after immunoprecipitations with 3E8 and HOPC-1 antibodies and the IgG-depleted plasma after its treatment with GammaBind Plus Sepharose were analyzed in the same way to check their 3 '-exonucleolytic activity toward unmodified oligonucleotide 1.

\section{RESULTS}

\section{Substrate specificity of the plasma 3'-exonuclease}

To characterize the enzymatic activity of the 3 '-exonuclease, the kinetic parameters for the cleavage of the unmodified (1-2) and phosphorothioate (3) oligomers were determined (Table 2). The $\mathrm{K}_{\mathrm{m}}$ and maximal rate $\left(\mathrm{V}_{\max }\right)$ values corresponded, respectively, to $16.0 \mu \mathrm{M}$ and 1.0 $\mu \mathrm{M} /$ minute for $\mathrm{PO}-\mathrm{d}\left[\mathrm{T}_{12}\right]$ and $71.5 \mu \mathrm{M}$ and 2.4 $\mu \mathrm{M} /$ minute for PO-d $\left[\mathrm{A}_{12}\right]$. In agreement with the results of Eder et al. (1991), unmodified oligonucleotides containing pyrimidines are cleaved more rapidly than purine-rich oligomers. Significant differences in the $\mathrm{K}_{\mathrm{m}}$ values for the unmodified $\mathrm{PO}-\mathrm{d}\left[\mathrm{T}_{12}\right]$ oligomer and its phosphorothioate counterpart, i.e., $\left[\mathrm{R}_{\mathrm{P}}-\mathrm{PS}\right]-\mathrm{d}\left[\mathrm{T}_{12}\right]$ were also observed (16 $\mu \mathrm{M}$ and $173 \mu \mathrm{M}$, respectively).

In our earlier studies, we have shown that 3 '-exonuclease present in human plasma hydrolyzes internucleotide 
phosphorothioate linkages of the $\left[\mathrm{R}_{\mathrm{P}}\right]$-configuration, whereas phosphorothioate linkages of the $\left[\mathrm{S}_{\mathrm{p}}\right]$-configuration are resistant toward its action (Koziolkiewicz et al., 1997). This means that the single $\left[S_{\mathrm{P}}\right]$-phosphorothioate bond located at the 3' ends of PS-oligos (e.g., in oligonucleotide 4, Table 2) may effectively stabilize them in vivo. To find how the single phosphorothioate internucleotide linkage located at the $3^{\prime}$ end protects unmodified oligonucleotide against the plasma 3 '-exonuclease, we synthesized several chimeric PO/PS octanucleotides (5, $9,10,11)$ of the sequences given in Table 1 . The single phosphorothioate internucleotide bond at the $3^{\prime}$ end of these oligonucleotides significantly protected them against the $3^{\prime}$-exonucleolytic hydrolysis, and, after 2hour incubation, oligomers $5,9,10$, and 11 were degraded only in $35 \%, 21 \%, 22 \%$, and $20 \%$, respectively. After 8 hours of incubation, at $37^{\circ} \mathrm{C}$ the extent of their degradation was for them $(5,9,10,11), 75 \%, 35 \%, 45 \%$, and $25 \%$, respectively. For comparison, under the same conditions, unmodified oligomers 1 and 8 were completely degraded after 2 hours. These results indicate that even a single phosphorothioate internucleotide bond located at the $3^{\prime}$ end of a PO-oligonucleotide can effectively elongate its half-life from several minutes to several hours.

The autoradiograms suggest that the partial degradation of the oligomer 11 results from an endonucleolytic activity (so called "hopping effect") of the enzyme rather than its ability to degrade the $\mathrm{S}_{\mathrm{P}}$-phosphorothioate internucleotide bond, because the $\mathrm{d}\left[\mathrm{T}_{\mathrm{PO}} \mathrm{C}_{\mathrm{PO}} \mathrm{T}_{\mathrm{PO}} \mathrm{T}_{\mathrm{PO}} \mathrm{T}_{\mathrm{PO}} \mathrm{T}_{\mathrm{PO}} \mathrm{T}\right]$ heptamer was not detected among the products of the oligomer 11 cleavage, whereas shorter oligomers were easily observed. The $\mathrm{d}\left[\mathrm{T}_{\mathrm{PO}} \mathrm{C}_{\mathrm{PO}} \mathrm{T}_{\mathrm{PO}} \mathrm{T}_{\mathrm{PO}} \mathrm{T}_{\mathrm{PO}} \mathrm{T}\right]$ hexamer generated by this cleavage does not contain any phosphorothioate function and therefore it becomes a much more acceptable substrate for the enzyme than octamer 11. For this reason, during incubation times longer than 2 hours the extent of the hydrolysis of octamer 11 changes only slightly (see Table 3 ). Another exonuclease that possesses an intrinsic endonuclease activity is snake venom phosphodiesterase (svPDE) from Crotalus adamanteus (Pritchard et al., 1977; Stoynov et al., 1997). It has been suggested that the ability of svPDE to hydrolyze an oligonucleotide substrate in an endonucleolytic manner results from limited processivity of the enzyme (Stoynov et al., 1997).

\section{Stereochemical course of 3'-exonuclease}

The stereochemical course of cleavage by human plasma 3'-exonuclease was determined with the use of our enzymatic methodology described elsewhere (Koziolkiewicz et al., 2002). Briefly, the phosphorothioate substrate PS-d[A $]_{6}$ (12) containing at the $3^{\prime}$ end two consecutive phosphorothioate internucleotide bonds of $R_{P}$ configuration labeled in the nonbridging positions with $\left[{ }^{18} \mathrm{O}\right]$ oxygen was incubated in human plasma. The resulting deoxyadenosine-5'-phosphorothioate was phosphorylated by adenylate and pyruvate kinases (Connolly et al., 1984) with the formation of $\operatorname{dATP} \alpha \mathrm{S}$, which was used in the next step for enzymatic elongation of the oligonucleotide starter $\mathrm{d}[\mathrm{A}]_{6}$ by terminal deoxyribonucleotidyl transferase (TdT). The resulting heptamer $\mathrm{d}[\mathrm{A}]_{5} \mathrm{~A}_{\mathrm{PS}} \mathrm{A}$ was analyzed by MALDI-TOF mass spectrometry to confirm loss or retention of the $\left[{ }^{18} \mathrm{O}\right]$ oxygen, which is dependent upon the mode of action demon-

Table 3. Susceptibility of Chimeric PO/PS-Oligo to the 3'-Exonuclease Degradation

\begin{tabular}{|c|c|c|c|}
\hline \multirow[b]{2}{*}{$\begin{array}{l}\text { Symbol } \\
\text { of oligonucleotide }\end{array}$} & \multirow[b]{2}{*}{$\begin{array}{l}\text { Oligonucleotide sequence } \\
\qquad 5^{\prime} \rightarrow 3^{\prime}\end{array}$} & \multicolumn{2}{|c|}{$\begin{array}{c}\text { Extent of degradation } \\
\text { in 50\% human plasma } \\
\text { (\%) }\end{array}$} \\
\hline & & $\begin{array}{c}\text { After } 2 \\
\text { hours }\end{array}$ & $\begin{array}{c}\text { After } 8 \\
\text { hours }\end{array}$ \\
\hline 1 & {$[\mathrm{PO}]-\mathrm{d}\left[\mathrm{T}_{12}\right]$} & 100 & \\
\hline 3 & {$\left[\mathrm{R}_{\mathrm{P}}-\mathrm{PS}\right]-\mathrm{d}\left[\mathrm{T}_{12}\right]$} & 25 & 75 \\
\hline 5 & {$[\mathrm{PO} / \mathrm{Mix}-\mathrm{PS}]-\mathrm{d}\left[\mathrm{T}_{\mathrm{PO}} \mathrm{T}_{\mathrm{PO}} \mathrm{T}_{\mathrm{PO}} \mathrm{T}_{\mathrm{PO}} \mathrm{T}_{\mathrm{PO}} \mathrm{T}_{\mathrm{PO}} \mathrm{T}_{\mathrm{PO}} \mathrm{T}_{\mathrm{PO}} \mathrm{T}_{\mathrm{PO}} \mathrm{T}_{\mathrm{PO}} \mathrm{T}_{\mathrm{PS}} \mathrm{T}\right]$} & 35 & 75 \\
\hline 8 & {$[\mathrm{PO}]-\mathrm{d}[\mathrm{TCTTTTTC}]$} & 100 & \\
\hline 9 & {$[\mathrm{PO} / \mathrm{Mix}-\mathrm{PS}]-\mathrm{d}\left[\mathrm{T}_{\mathrm{PO}} \mathrm{C}_{\mathrm{PO}} \mathrm{T}_{\mathrm{PO}} \mathrm{T}_{\mathrm{PO}} \mathrm{T}_{\mathrm{PO}} \mathrm{T}_{\mathrm{PO}} \mathrm{T}_{\mathrm{PS}} \mathrm{C}\right]$} & 21 & 35 \\
\hline 10 & {$\left[\mathrm{PO} / \mathrm{R}_{\mathrm{P}}-\mathrm{PS}\right]-\mathrm{d}\left[\mathrm{T}_{\mathrm{PO}} \mathrm{C}_{\mathrm{PO}} \mathrm{T}_{\mathrm{PO}} \mathrm{T}_{\mathrm{PO}} \mathrm{T}_{\mathrm{PO}} \mathrm{T}_{\mathrm{PO}} \mathrm{T}_{\mathrm{PS}} \mathrm{C}\right]$} & 22 & 45 \\
\hline 11 & {$\left[\mathrm{PO} / \mathrm{S}_{\mathrm{P}}-\mathrm{PS}\right]-\mathrm{d}\left[\mathrm{T}_{\mathrm{PO}} \mathrm{C}_{\mathrm{PO}} \mathrm{T}_{\mathrm{PO}} \mathrm{T}_{\mathrm{PO}} \mathrm{T}_{\mathrm{PO}} \mathrm{T}_{\mathrm{PO}} \mathrm{T}_{\mathrm{PS}} \mathrm{C}\right]$} & 20 & 25 \\
\hline
\end{tabular}

"PO" and "PS" letters mean internucleotide phosphodiester and phosphorothioate bonds, respectively. The 5'$\left[{ }^{32} \mathrm{P}\right]$-labeled substrates $(5 \mu \mathrm{M})$ were incubated in $50 \%$ human plasma at $37^{\circ} \mathrm{C}$. At various times $10-\mu \mathrm{L}$ aliquotes containing a mixture of oligonucleotides were withdrawn, and extractable oligonucleotides were analyzed using $20 \%$ polyacrylamide and $7 \mathrm{M}$ urea gel electrophoresis followed by autoradiography and quantitative phosphorimaging. 
strated by the nuclease of interest. In the case of $\mathrm{R}_{\mathrm{P}}$-selective enzyme, loss of the chemically incorporated $\left[{ }^{18} \mathrm{O}\right]$ oxygen (Guga et al., 2001) proved that the $3^{\prime}$ exonuclease-catalyzed hydrolysis proceeds by a two-step mechanism with the formation of an enzyme-covalent intermediate. A detailed description of the above-mentioned procedure and general rules for this assignment have been presented earlier (Koziolkiewicz et al., 2002). This result allowed us to formulate the hypothesis that human plasma 3 '-exonuclease belongs to the NPP family (Belli et al., 1993; Frittitta et al., 1999; Goding et al., 2003).

\section{Differential effects of inhibitors}

In the first step of these experiments, we have used an unmodified pyrimidine-rich dodecanucleotide d[TCCTCTTTTTTT] (7) $(5 \mu \mathrm{M})$ as the substrate for the human plasma $3^{\prime}$-exonuclease. Compounds reported earlier as substrates or inhibitors of NPPs were used as potential inhibitors of the 3'-exonuclease. We have tested the inhibitory effect for selected NPP substrates (ATP, $\mathrm{Ap}_{4} \mathrm{~A}$, and $p$-nitrophenyl-TMP) (Gijsbers et al., 2003; Vollmayer et al., 2003), their phosphorothioate analogs (ATP $\alpha \mathrm{S}, \mathrm{CTP} \alpha \mathrm{S}, \mathrm{dATP} \alpha \mathrm{S}$, or ATP $\gamma \mathrm{S}$ ), heparin, and PPADS (Hosoda et al., 1999; Grobben et al., 2000), or phosphorothioate analogs of nucleoside-5' -phosphates generated by the enzyme as the products (dAMPS and other dNMPS). $\mathrm{IC}_{50}$ values for these compounds are presented in Tables 4 and 5. The most effective inhibitors of the $3^{\prime}$-exonuclease are $\operatorname{ATP} \alpha \mathrm{S}$ and $\operatorname{dATP} \alpha \mathrm{S}\left(\mathrm{IC}_{50}=\right.$ $0.2-2.0 \mu \mathrm{M})$ and $\mathrm{CTP} \alpha \mathrm{S}\left(\mathrm{IC}_{50}=8.4 \mu \mathrm{M}\right)$. The phosphorothioate analog of ATP containing a sulfur atom in the $\gamma$ position appeared to be a worse inhibitor of the degradation of oligonucleotide 7 than adenosine- or cytidine-( $\alpha$-thio)triphosphates $\left(\mathrm{IC}_{50}\right.$ for $\left.\mathrm{ATP} \gamma \mathrm{S}=27 \mu \mathrm{M}\right)$. Among deoxynucleoside-5'-phosphorothioates, only dAMPS and dCMPS (used at a concentration of 20-50 $\mu \mathrm{M}$ ) inhibited $40-50 \%$ degradation of oligonucleotide 7 (data not shown). The $3^{\prime}$-exonuclease was slightly inhibited by heparin and PPADS (see Table 4). We have also used lysophosphatidylcholine $(0.1-40 \mathrm{mM})$ as a potential inhibitor of the 3 '-exonuclease, but in this case no inhibition was observed.

\section{Limited diastereoselectivity of $d A T P \alpha S$ inhibitors}

Because $\mathrm{ATP} \alpha \mathrm{S}$ and $\mathrm{CTP} \alpha \mathrm{S}$ used in above-mentioned experiments have been synthesized via enzymatic phosphorylation catalyzed by adenylate and pyruvate kinases, they were obtained as diastereomerically pure species of $\mathrm{S}_{\mathrm{P}}$ absolute configuration. For more detailed analysis of the inhibitory effect observed for nucleside $(\alpha$ thio)triphosphates, we carried out additional experiments using the $R_{P}$ and $S_{P}$ diastereomers synthesized by the oxathiaphospholane method (Misiura et al., 2005). In-
Table 4. Inhibition of Degradation of [PO]d[TCCTCTTTTTTT] DODECAMER (7) BY NPP Substrates OR Their ANAlogs

\begin{tabular}{lc}
\hline Inhibitor & $I_{50}(\mu M)$ \\
\hline $\mathrm{S}_{\mathrm{P}}-\mathrm{ATP} \alpha \mathrm{S}$ & 1.4 \\
$\mathrm{~S}_{\mathrm{P}}-\mathrm{dATP} \alpha \mathrm{S}$ & 1.5 \\
$\mathrm{R}_{\mathrm{P}}-\mathrm{dATP} \mathrm{S}$ & 5.0 \\
$\mathrm{~S}_{\mathrm{P}}-\mathrm{CTP} \alpha \mathrm{S}$ & 8.4 \\
$p$-Nitrophenyl-TMP & 27 \\
$\mathrm{ATP} \gamma \mathrm{S}$ & 27 \\
$\mathrm{Ap}_{4} \mathrm{~A}$ & 37 \\
$\mathrm{ATP}$ & 54 \\
PPADS & 71 \\
UDP-glucose & 106 \\
Lysophosphatidylcholine & No inhibition up to $40 \mathrm{mM}$ \\
Heparin $^{\mathrm{b}}$ & $\sim 10-15 \mathrm{mg} / \mathrm{mL}$ \\
\hline
\end{tabular}

aNPP inhibitor according to Grobben et al. (2000).

bNPP inhibitor according to Hosoda et al. (1999).

Different concentrations of the inhibitors were added to $50 \%$ human plasma, and the resultant mixtures were preincubated for 5 minutes at $37^{\circ} \mathrm{C}$. After the addition of the oligonucleotide substrate $(5 \mu \mathrm{M})$, incubation of the samples was prolonged to 2 hours. Products of the oligonucleotide degradation were recovered from the incubation mixtures and analyzed as described above. The densitometric analysis of these shorter oligomers allowed calculation of the level of $5^{\prime}$-mononucleotides released as the final products during the incubation time. For the isomers of $\mathrm{dATP} \alpha \mathrm{S}$, the experiments were performed in duplicate with the standard deviation $<10 \%$ among duplicates. Other compounds listed in the table are in triplicate with the standard deviation $<15 \%$ among triplicates.

hibitory effects of the dATP $\alpha$ S diastereomers expressed as their $\mathrm{IC}_{50}$ values are presented in Table 5. As the substrates for the $3^{\prime}$-exonuclease, we have used two unmodified oligonucleotides (2 and 7) and the oligomer $\left[\mathrm{R}_{\mathrm{P}}-\mathrm{PS}\right]-\mathrm{d}\left[\mathrm{A}_{12}\right]$ (6) containing exclusively internucleotide bonds of $R_{P}$ configuration. For the unmodified dodecanucleotides, the $\mathrm{S}_{\mathrm{P}}$-dATP $\alpha \mathrm{S}$ isomer was slightly more effective than its $R_{P}$ counterpart. However, in the case of the phosphorothioate oligonucleotide 6 (used at a $5 \mu \mathrm{M}$ concentration), the $\mathrm{IC}_{50}$ value for the $\mathrm{S}_{\mathrm{P}}-\mathrm{dATP} \alpha \mathrm{S}$ was 0.2 $\mu \mathrm{M}$, whereas that for the $\mathrm{R}_{\mathrm{P}}$ isomer was 10 times higher $(2 \mu \mathrm{M})$ (see Table 5).

Independent experiments have shown that both, $\mathrm{S}_{\mathrm{P}}$ and $\mathrm{R}_{\mathrm{P}}$ isomers of dATP $\alpha \mathrm{S}$ were degraded in $50 \%$ human plasma with the formation of $\operatorname{dADP} \alpha \mathrm{S}$ and dAMPS, but the rates of the dATP $\alpha \mathrm{S} \rightarrow \mathrm{dADP} \alpha \mathrm{S} \rightarrow$ dAMPS conversion were different for each of the substrates (see legend to Table 5). One can suppose that not only dATP $\alpha \mathrm{S}$ but also $\mathrm{dADP} \alpha \mathrm{S}$ or dAMPS bind to the binding site of the 
TABle 5. Inhibitory EfFects of THE dATP $\alpha$ S Diastereomers on the Oligonucleotide Hydrolysis

\begin{tabular}{lccc}
\hline & \multicolumn{3}{c}{$I C_{50}(\mu M)$} \\
\cline { 2 - 4 } & {$[P O]-d\left[A_{12}\right](2)$} & {$\left[R_{P}-P S\right]-d\left[A_{12}\right](6)$} & [PO]-d[TCCTCTTTTTTT] (7) \\
\hline $\mathrm{R}_{\mathrm{P}}$-dATP $\alpha \mathrm{S}^{\mathrm{a}}$ & 5.0 & 2.0 & 5.0 \\
$\mathrm{~S}_{\mathrm{P}}-\mathrm{dATP} \alpha \mathrm{S}^{\mathrm{a}}$ & 2.0 & 0.2 & 1.5 \\
\hline
\end{tabular}

The inhibitors $(0.02-5 \mu \mathrm{M})$ were added to $50 \%$ human plasma and the resultant mixtures were preincubated for 5 minutes at $37^{\circ} \mathrm{C}$. After the addition of the oligonucleotides 7, 2, and 6 (each of them at a $5 \mu \mathrm{M}$ concentration), incubation of the samples was prolonged to 2, 6, and 16 hours, respectively. All experiments were performed in duplicate with the standard deviation $<10 \%$ among duplicates.

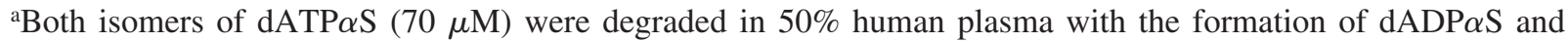
dAMPS but rates of the dATP $\alpha \mathrm{S} \rightarrow \mathrm{dADP} \alpha \mathrm{S} \rightarrow \mathrm{dAMPS}$ conversion were different for each of the diastereomers: in the case of $\mathrm{S}_{\mathrm{P}}$-dATP $\alpha \mathrm{S}$ after its $2 \mathrm{~h}$-incubation the reaction mixture contained $25 \%$ of the $\mathrm{S}_{\mathrm{p}}$-dATP $\alpha \mathrm{S}, \sim 50 \%$ of the $\mathrm{S}_{\mathrm{P}}-\mathrm{dATP} \alpha \mathrm{S}$ and $\sim 25 \%$ of the dAMPS. After $6 \mathrm{~h}$-incubation the reaction mixture contained dADP $\alpha \mathrm{S}(25 \%)$ and dAMPS (75\%), while after 16 hours the reaction mixture contained only dAMPS (as analyzed by HPLC).

For the $\mathrm{R}_{\mathrm{P}}-\mathrm{dATP} \alpha \mathrm{S}$ after 2 hours of incubation, the reaction mixture contained $10 \%$ of the $\mathrm{R}_{\mathrm{P}}-\mathrm{dATP} \alpha \mathrm{S}, \sim 20 \%$ of the $\mathrm{R}_{\mathrm{P}}-\mathrm{dADP} \alpha \mathrm{S}$, and $\sim 70 \%$ of dAMPS. After 6 hours, the reaction mixture contained dAMPS (90\%) and $\mathrm{dADP} \alpha \mathrm{S}(10 \%)$, whereas after 16 hours the dAMPS was the only nucleotide product present in the reaction mixture (as analyzed by HPLC).

enzyme and inhibit PS-oligo cleavage. Among abovementioned nucleoside tri-, di-, or monophosphates, the $\mathrm{S}_{\mathrm{P}}$-dATP $\alpha \mathrm{S}$ and, probably, $\mathrm{S}_{\mathrm{P}}-\mathrm{dADP} \alpha \mathrm{S}$ can be considered as good inhibitors of the human plasma $3^{\prime}$-exonuclease.

\section{3'-Exonuclease activity of immune precipitates}

Immunoprecipitations of human plasma were carried out using two different monoclonal antibodies (Belli et al., 1993). Earlier studies have shown that mouse 3E8 monoclonal anti-PC-1 antibodies were able to bind the native form of human PC-1 (NPP1) and did not inhibit its phosphodiesterase activity (Belli et al., 1993). The HOPC-1 antibody was used as an isotype-matched negative control. The immunoprecipitates obtained as described in Materials and Methods were used for degradation of unmodified oligonucleotide $[\mathrm{PO}]-\mathrm{d}\left[\mathrm{T}_{12}\right](1)$ and, independently, for degradation of oligonucleotide 3 containing internucleotide phosphorothioate linkages of the $\mathrm{R}_{\mathrm{P}}$ configuration. In the case of the phosphorothioate oligonucleotide 3 , the incubation time had to be prolonged from the standard 8 hours to 24 hours. Taking into account the prolonged time of incubation and previously reported phosphatase activity of PC-1 (Bollen et al., 2000), we carried out the 5'-labeling of the substrate and the resulting products as the final step after incubation of the oligonucleotides with the immunoprecipitates and denaturation of the samples. Then, the samples were analyzed by PAGE in $20 \%$ denaturing gel (Figs. 1 and 2). The results clearly show that the immunoprecipitate comprising the complex of human plasma PC-1 and the monoclonal antibody $3 \mathrm{E} 8$ possesses 3 '-exonucleolytic activity toward unmodified and phosphorothioate oligonucleotides containing internucleotide bonds of the $\mathrm{R}_{\mathrm{P}}$ configuration.

The 3'-exonucleolytic activity of the supernatants obtained after immunoprecipitations with 3E8 and HOPC-1 antibodies and the IgG-depleted plasma after its treatment with GammaBind Plus Sepharose was analyzed in

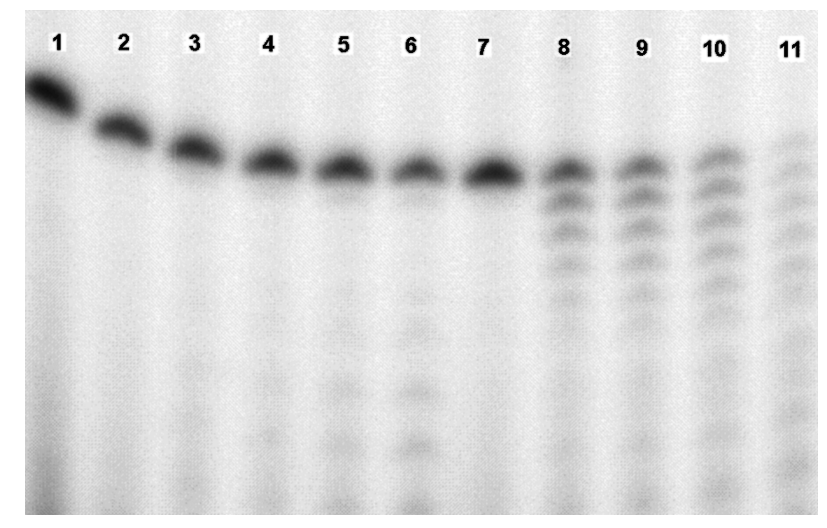

FIG. 1. 3'-Exonucleolytic activity of immunoprecipitates obtained with the use of anti-NPP1 monoclonal antibody 3E8 and control monoclonal antibody HOPC-1. In both cases, unmodified oligonucleotide $[\mathrm{PO}]-\mathrm{d}\left[\mathrm{T}_{12}\right]$ (1) was used as the substrate: lane 1, the oligomer 1 used as a control; lanes 2-6, the substrate 1 incubated with control HOPC-1 immunoprecipitate for $0,0.5$, 1,2 and 4 hours, respectively; lanes 7-11, the substrate 1 incubated with $3 \mathrm{E} 8$ immunoprecipitate for $0,0.5,1,2$, and 4 hours, respectively. 


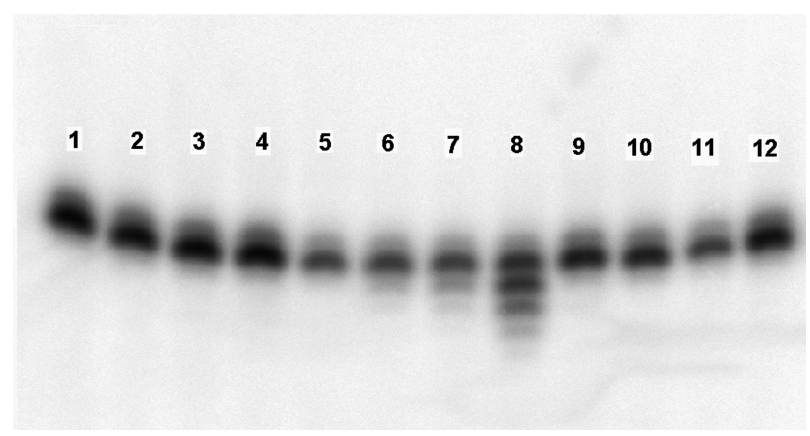

FIG. 2. 3'-Exonucleolytic activity of immunoprecipitates obtained with the use of monoclonal anti-NPP1 antibody 3E8 and control monoclonal antibody HOPC-1 toward stereoregular PSoligonucleotide $\left[\mathrm{R}_{\mathrm{P}}-\mathrm{PS}\right]-\mathrm{d}\left[\mathrm{T}_{12}\right]$ (3): lanes $1-4$, the substrate incubated with Sepharose $\mathrm{G}$ beads (alone) for $0,4,8$, and 24 hours; lanes 5-8, the oligonucleotide 3 incubated with 3E8 antibodies for $0,4,8$, and 24 hours; lanes $9-12$, the same substrate 3 incubated with control HOPC-1 antibodies for $0,4,8$, and 24 hours.

the same way. This experiment confirmed that the IgGdepleted plasma as well as the supernatant obtained after separation of HOPC-1 immunoprecipitate retained their $3^{\prime}$-exonucleolytic activity, whereas the supernatant obtained after separation of the 3E8 immunoprecipitate showed barely detectable activity (data not shown).

\section{DISCUSSION}

Previously, we have shown that hydrolysis of PS-oligos catalyzed by human plasma $3^{\prime}$-exonuclease proceeds by a two-step mechanism with participation of a covalent enzyme-substrate intermediate (Koziolkiewicz et al., 2002). This two-step mechanism is not very common among enzymes involved in nucleotide degradation: only bovine intestinal mucosa 5'-nucleotide phosphodiesterase, alkaline phosphatase and snake venom phosphodiesterase act via a double-displacement mechanism (Eckstein et al., 1979a,b; Cummins and Potter, 1987). A similar mechanism was also proposed for NPPs (Gijsbers et al., 2001). Taking into account the same stereochemical mode of action of the 3 '-exonuclease and NPP proteins, we postulated that the enzyme degrading in vivo PS-oligos belongs to the NPP family.

Mammalian genomes contain at least seven genes encoding members of this family, but only three of them (NPP1, NPP2, and NPP3) have been studied in detail (Bollen et al., 2000; Goding et al., 2003). NPP1, also known as a plasma cell antigen PC-1, is the best-characterized member of the NPP family. The NPP1-3 are expressed as membrane-bound or secreted forms that release nucleoside 5 '-monophosphates from a variety of nucleotides and nucleotide derivatives (Belli et al., 1993;
Goding et al., 2003). These enzymes require two divalent metal ions (termed Me1 and Me2), which are involved in the formation of a nucleotidylated threonine in the active site and the subsequent release of nucleoside 5'monophosphate (Fig. 3). Moreover, recent studies have revealed that some members of the family recognize and degrade substrates, being neither nucleotides nor their derivatives. NPP2, also known as autotaxin, appeared to be identical to lysophospholipase $\mathrm{D}$, which hydrolyses lysophosphatidylcholine into lysophosphatidic acid and choline (Tokumura et al., 2002; Umezu-Goto et al.,
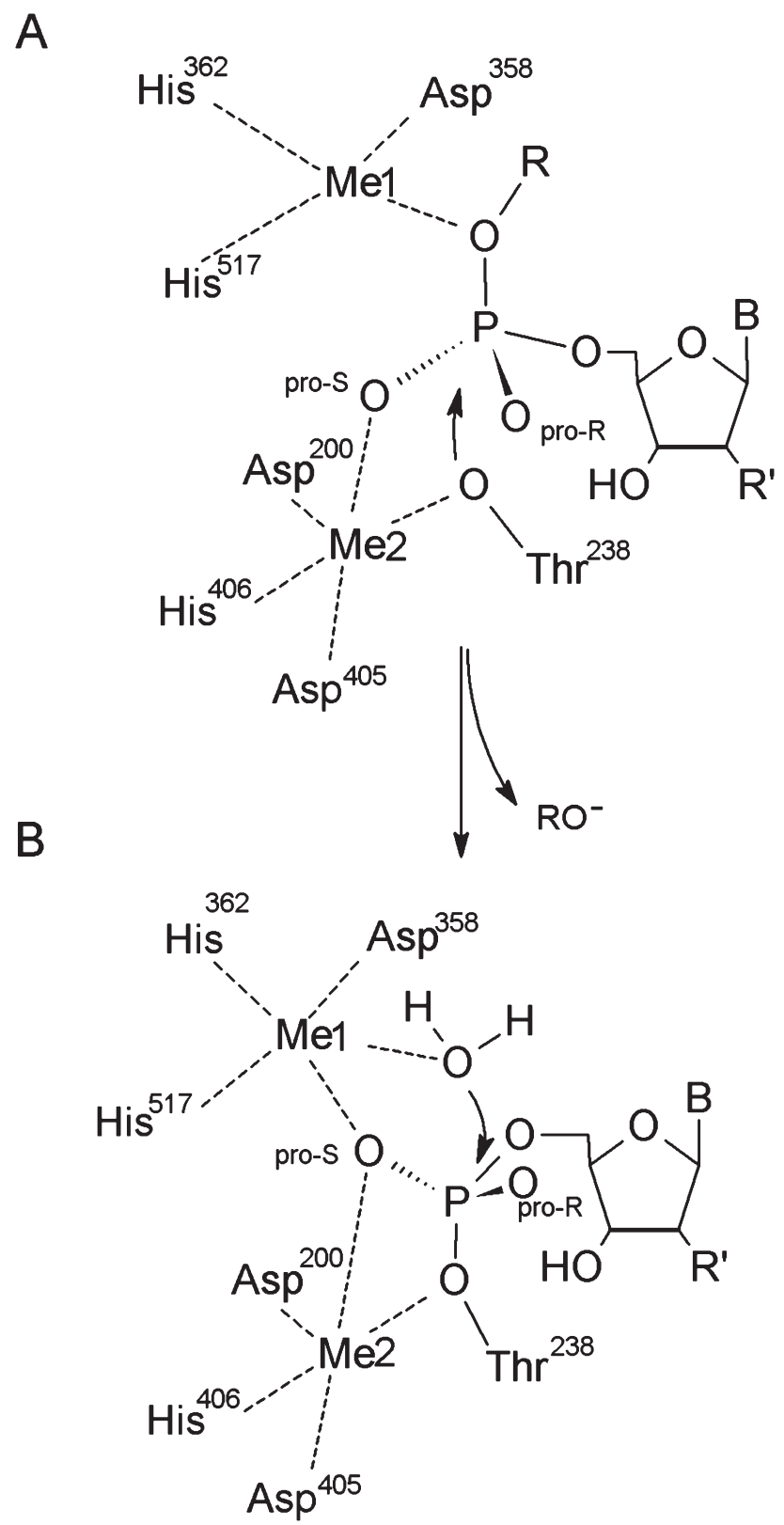

FIG. 3. Scheme presenting contacts between the NPP activesite structure elements and nucleoside triphosphate or nucleoside ( $\alpha$-thio)triphosphate (based on the model of Gijsbers et al., 2001). $\mathrm{R}$ refers to a pyrophosphate; $\mathrm{R}^{\prime}$ means $\mathrm{H}$ or $\mathrm{OH}$. 
2002). Biological function of NPP3 is not known. Considering its substrate specificity, NPP3 more closely resembles NPP1 than NPP2 (Gijsbers et al., 2003). The physiological role of NPP seems to be largely regulatory rather than metabolic (Goding et al., 2003). Due to their various enzymatic activities, NPPs have multiple roles, including signal transduction by transmembrane receptors of nucleotides or lysophosphatidic acid, stimulation of cell motility, tumor metastasis, regulation of tissue calcification, nucleotide recycling, and, probably, regulation of the insulin receptor (Goding et al., 2003).

To confirm our hypothesis that $3^{\prime}$-exonuclease belongs to the NPP family, we used several compounds, known to be substrates of NPP proteins, as potential competitive inhibitors of the 3'-exonucleolytic cleavage of oligonucleotides (Tables 4 and 5). Nucleoside $5^{\prime}$-( $\alpha$-thio)triphosphates, mainly $\operatorname{ATP} \alpha \mathrm{S}$ and $\mathrm{dATP} \alpha \mathrm{S}$, appeared to be the most effective inhibitors: at $0.2-2.0 \mu \mathrm{M}$ concentration they effectively inhibited the degradation of the PO- and PS-oligonucleotides 2,6 , and 7 used at a $5 \mu \mathrm{M}$ concentration. Moreover, the $\mathrm{S}_{\mathrm{P}}-\mathrm{dATP} \alpha \mathrm{S}$ appeared to be 10fold more effective inhibitor than its $\mathrm{R}_{\mathrm{P}}$ counterpart.

Due to phosphatase and pyrophosphatase activities of the human plasma NPP, both isomers of $\operatorname{dATP} \alpha \mathrm{S}$ were degraded in 50\% human plasma but rates of the $\mathrm{dATP} \alpha \mathrm{S} \rightarrow \mathrm{dADP} \alpha \mathrm{S} \rightarrow$ dAMPS conversion were different for each of the substrates (see legend to Table 5). One can suppose that dATP $\alpha$, dADP $\alpha$, or dAMPS bind to the binding site of the enzyme, but their inhibitory effects have not been measured so far. Recently Zalatan et al. (2006) determined the X-ray structure of a complex of bacterial NPP with $5^{\prime}$-AMP and found two zinc ions close to the $5^{\prime}$-phosphate moiety in the catalytic site. No structural information is available for eukaryotic NPP proteins, but mutagenesis experiments clearly indicate that they have similar active sites with two metal ions (probably $\mathrm{Zn}^{2+}$ ) (Gijsbers et al., 2001). Little is known about the determinants for NPP affinity toward nucleoside tri-, di-, or monophosphates, but the thiophilic character of zinc ion may result in strong interactions with a sulfur atom present in dATPaS, dADPaS, or dAMPS and may affect the binding of these molecules in the active center.

In the case of the pyrophosphatase mode of the NPP action (direct dATP $\alpha \mathrm{S} \rightarrow$ dAMPS conversion), ATP and its phosphorothioate analogs (ATP $\alpha \mathrm{S}, \operatorname{dATP} \alpha \mathrm{S}, \operatorname{ATP} \gamma \mathrm{S}$, and $\mathrm{dATP} \gamma \mathrm{S})$ are bound in the catalytic site. The Me2activated nucleophilic hydroxyl of the catalytic threonine attacks the $\alpha$-phosphate of the incoming substrate, resulting in the generation of a covalent nucleotidylated intermediate (Gijsbers et al., 2001) (Fig. 3A). In the second catalytic step, a Me1-activated water molecule attacks this intermediate to regenerate the threonine residue and release a (deoxy)nucleoside $5^{\prime}$-phosphate or (deoxy)nucleoside $5^{\prime}$-phosphorothioate (Fig. 3B). On the basis of the reaction mechanism proposed by Gijsbers et al. (2001) and on our results concerning stereoselective inhibitory effect of $\mathrm{dATP} \alpha \mathrm{S}$, it can be hypothesized that the pro- $\mathrm{S}_{\mathrm{P}}$ oxygen coordinates both metal ions (Fig. 3). The presence of a sulfur atom instead of the pro- $\mathrm{S}_{\mathrm{P}}$ oxygen atom makes possible the binding of the substrate to the Me 2 and the formation of the covalent, nucleotidylated intermediate, but also significantly disturbs the second step of the reaction, namely hydrolysis of the intermediate. If this oxygen is replaced by bulky sulfur atom, the location of water in the proximity of the attacked phosphorus may be disturbed because of changes in the catalytic site architecture. One can hypothesize that the pro- $R_{P}$ oxygen atom is not involved in such tight contacts with the active-site structure elements (Fig. 3), and its substitution by sulfur atom changes the architecture of the active site to a lower extent. Therefore, the $\mathrm{R}_{\mathrm{P}}$ isomers of nucleoside phosphorothioates are less potent inhibitors than their $\mathrm{S}_{\mathrm{P}}$ counterparts.

On the other hand, ATP $\alpha$ S and dATP $\alpha$ S were more effective inhibitors $\left(\mathrm{IC}_{50}<2 \mu \mathrm{M}\right)$, than ATP $\gamma \mathrm{S}$ and ATP $\left(\mathrm{IC}_{50}\right.$ for ATP $\gamma \mathrm{S}$ was $\left.27 \mu \mathrm{M}\right)$. Cytidine-5' $-(\alpha-$ thio)triphosphate $(\mathrm{CTP} \alpha \mathrm{S})$ was a less effective inhibitor than $\mathrm{ATP} \alpha \mathrm{S}\left(\mathrm{IC}_{50}\right.$ for $\mathrm{CTP} \alpha \mathrm{S}$ was $\left.8.4 \mu \mathrm{M}\right)$. The best documented physiological roles of NPP require the degradation of ATP rather than CTP (Goding et al., 2003), and their affinity to ATP is probably higher than the affinity to other nucleoside $5^{\prime}$-triphosphates.

Other compounds listed in Table 4 were much worse inhibitors of the 3 '-exonucleolytic activity than nucleoside $5^{\prime}$ - $(\alpha$-thio)triphosphates. Although heparin and PPADS have been reported as inhibitors of NPP activity (Hosoda et al., 1999; Grobben et al., 2000), we observed only slight inhibitory effects of these compounds. It should be also noted that lysophosphatidylcholine, even at a $40 \mathrm{mM}$ concentration, did not inhibit the degradation of the oligonucleotide 7 (5 $\mu \mathrm{M}$ concentration). This result suggests that NPP2 possessing lysophospholipase D activity did not recognize and degrade oligonucleotide substrates.

The unmodified oligonucleotides 1 and 2 used in our studies were degraded with a $\mathrm{K}_{\mathrm{m}}$ of $16 \mu \mathrm{M}$ and $71.5 \mu \mathrm{M}$, respectively. These values can confirm the different affinities of the $3^{\prime}$-exonuclease for purine- and pyrimidine-rich oligonucleotides observed previously by Eder et al. and other authors (Eder et al., 1991; Koziolkiewicz et al., 1997; Gilar et al., 1998). It should be noticed that $\mathrm{K}_{\mathrm{m}}$ values and rates of the release of mononucleotides from oligonucleotides vary depending on their sequences and length (Table 2). On the basis of these kinetic data, one can conclude that the affinity of the enzyme toward oligonucleotides is comparable or even higher than that measured for p-nitrophenyl-TMP, which is routinely used as the substrate for NPP enzymes $\left(\mathrm{K}_{\mathrm{m}}\right.$ for $p$-nitrophenyl-TMP is $\sim 200 \mu \mathrm{M}$ ). Although it was earlier men- 
tioned that NPP can degrade phosphodiester internucleotide bonds in oligonucleotides (Bollen et al., 2000), no kinetic data for these substrates were reported. It remains to explain how oligonucleotide substrates, taking into account dimensions of their molecules, are recognized by the enzyme and how its nuclease-like domain participates in this process. It is known that this domain and DNA/RNA nonspecific endonucleases have common structural features (Bollen et al., 2000).

To confirm definitely our hypothesis that the 3 '-exonuclease is one of the NPP proteins, we used mouse monoclonal antibody 3E8, which is able to bind the native form of human plasma cell antigen PC-1 (NPP1) and does not inhibit phosphodiesterase activity of PC-1. The immunoprecipitates were used for degradation of unmodified oligonucleotide [PO]-d[ $\left.\mathrm{T}_{12}\right]$ (1) and, independently, for degradation of the oligomer 3 containing internucleotide phosphorothioate linkages of the $R_{P}$ configuration. The results clearly show that NPP1 (PC-1, EC 3.1.4.1/3.6.1.9) is responsible for the $3^{\prime}$-exonucleolytic activity of human plasma and degradation of phosphorothioate oligonucleotide. Although our results indicate that NPP1 but not NPP2 is responsible for the 3 '-exonucleolytic activity of human plasma, we could not determine whether NPP3 is also involved in degradation of oligonucleotides. It was earlier concluded that NPP1 and NPP3 are more closely related to each other than to NPP2 (autotaxin). Their substrate preferences are similar (Gijsbers et al., 2003). The traces of $3^{\prime}$-exonucleolytic activity of the supernatant obtained after separation of the 3E8 immunoprecipitate (data not shown) may result from the presence of a soluble form of NPP3 in the NPP1-depleted plasma obtained by the use of the $3 \mathrm{E} 8$ monoclonal antibodies.

These studies were designed to characterize the soluble NPP-like enzymes present in plasma but one cannot exclude that other proteins bound to membranes on various blood cells may also have phosphodiesterase and/or pyrophosphatase activities (Stefan et al., 2005) and may play a role in the degradation of PS-oligos. Moreover, it also seems possible that the NPP1, present on the external surface of membranes of hepatocytes or other cells, degrades the antisense PS-oligos in liver and other tissues. It is known that NPP1 and other members of this family can exist both as membrane-bound and soluble forms (Belli et al., 1993). The concentration of a soluble form of NPP1 in human plasma, measured by enzymelinked immunosorbent assay (ELISA), is $\sim 40 \mathrm{ng} / \mathrm{mL}$ ( $\sim 300-400 \mathrm{pM})$ (Frittitta et al., 1999), but the level of membrane-bound NPP1 in various tissues is difficult to quantitate (Goding et al., 2003). The identification of the 3 '-exonuclease as the NPP1 allows explanation of some effects observed for PS-oligos degraded in liver homogenates (Graham et al., 1998; Levin, 1999; Crooke et al., 2000). Inhibition of liver nucleases by phosphoroth- ioates reported by Crooke et al. (2000) probably results from the inhibition of NPP by dAMPS and dCMPS as we observed for the enzyme in human plasma. It is also known that AMP and CMP competitively inhibit NPP activity (Hosoda et al., 1999). Most probably, dNMPS resulting from degradation of PS-oligos inhibit membrane-bound NPP1 in the same way because the active sites of the membrane and soluble form are identical (Belli et al., 1993). It is also possible that dNMPS resulting from degradation of PS-oligons by NPP1 are subsequently phosphorylated by ecto-kinases giving rise to deoxynucleoside- $5^{\prime}-(\alpha$-thio)triphosphates $(\mathrm{dNTP} \alpha \mathrm{S})$ in this way (Yegutkin et al., 2002).

PS-oligos degradation by NPP1 considerably shortens their in vivo lifetime, which may limit their effectiveness. Identification of NPP1 as the major cause of in vivo degradation of PS-oligos may lead to the development of even more potent and specific inhibitors than the $\mathrm{S}_{\mathrm{P}^{-}}$ $\mathrm{dATP} \alpha \mathrm{S}$. In recent review (Stefan et al., 2005), NPPtype ectophosphodiesterases are considered as therapeutic targets, for which inhibitors and/or activators are desired.

However, levels of NPP1 activity in vivo are highly regulated. Its excessive activity has been associated with chondrocalcinosis due to deposition of calcium pyrophosphate dihydrate in cartilage (Terkeltaub, 2001), whereas lack of NPP1 causes idiopathic infantile arterial calcification in humans (Rutsch et al., 2003) and a syndrome of periarticular calcium deposition and osteoporosis in mice (Okawa et al., 1998; Sali et al., 1999). In summary, inhibition of NPP1 could have both beneficial and deleterious effects, and improved understanding of this enzyme may allow these effects to be controlled in useful ways.

\section{ACKNOWLEDGMENTS}

The authors thank Dr. Lucyna Wozniak and Marcin Góra for synthesis PO/PS chimeric oligonucleotides 9-11 and an anonymous referee for valuable suggestions and comments. These studies were financially assisted by the State Committee for Scientific Research (KBN), grant no. PBZ-KBN 059/T09/05 (to M.K.).

\section{REFERENCES}

BELLI, S.I., VAN DRIEL, I.R., and GODING, J.W. (1993). Identification and characterization of soluble form of the plasma cell membrane glycoprotein PC-1 (5'-nucleotide phosphodiesterase). Eur. J. Biochem. 217, 421-428.

BOLLEN, M., GIJSBERS, R., CEULEMENS, H., STALMANS, W., and STEFAN, C. (2000). Nucleotide pyrophosphatases/phosphodiesterases on the move. Crit. Rev. Biochem. Mol. Biol. 35, 393-432. 
CONNOLLY, B.A., ECKSTEIN, F, and PINGOUD, A. (1984). The stereochemical course of the restriction endonuclease Eco RI-catalyzed reaction. J. Biol. Chem. 259, 10760-10763.

CROOKE, R.M., GRAHAM, M.J., MARTIN, M.J., LEMONIDIS, K.M., WYRZYKIEWICZ, T., and CUMMINS L.L. (2000). Metabolism of antisense oligonucleotides in rat liver homogenates. J. Pharmacol. Exp. Ther. 292, 140-149.

CUMMINS, J.H., and POTTER, B.V. (1987). On the mechanism of action of bovine intestinal mucosa 5'-nucleotide phosphodiesterase. Stereochemical evidence for a nucleotidyl-enzyme intermediate. Eur. J. Biochem. 162, 123-128.

DIAS, N., and STEIN, C.A. (2002). Antisense oligonucleotides: basic concepts and mechanisms. Mol. Cancer Ther. 1, 347-355.

ECKSTEIN, F., BURGERS, P.M., and HUNNEMAN, D.H. (1979a). Stereochemistry of hydrolysis by snake venom phosphodiesterase. J. Biol. Chem. 254, 7476-78.

ECKSTEIN, F., BURGERS, P.M., SATYANARAYANA, B.K., and SAENGER W. (1979b) Crystal and molecular structure of adenosine 5'-O-phosphorothioate O-p-nitrophenylester (SP isomer). Substrate stereospecificity of snake venom phosphodiestrease. Eur. J. Biochem. 100, 585-591.

EDER, P.S., DEVINE, R.J., DAGLE, J.M., and WALDER, J.A. (1991). Substrate specificity and kinetics of degradation of antisense oligonucleotides by a 3 -exonuclease in plasma. Antisense Rev. Dev. 1, 141-151.

FRITTITTA, L., CAMASTRA, S., BARATTA, R., COSTANZO, B.V., D'ADAMO, M., GRACI, S., SPAMPINATO, D., MADDUX, B.A., VIGNERI, R., FERRANNINI, E., and TRISCHITTA V. (1999). A soluble PC-1 circulates in human plasma: relationship with insulin resistance and associated abnormalities. J. Clin. Endocrinol. Metab. 9, 3620-3625.

GIJSBERS, R., CEULEMANS, H., STALMANS, W., and BOLLEN, M. (2001). Structural and catalytic similarities between nucleotide pyrophosphatases/phosphodiesterases and alkaline phosphatases. J. Biol. Chem. 276, 1361-1368.

GIJSBERS, R., AOKI, J., ARAI, H., and BOLLEN, M. (2003). The hydrolysis of lysophospholipids and nucleotides by autotaxin (NPP2) involves a single catalytic site. FEBS Lett. 538, 60-64.

GILAR, M., BELENKY, A., BUDMAN, Y., SMISEK, D.L., and COHEN, A.S. (1998). Impact of $3^{\prime}$-exonuclease stereoselectivity on the kinetics of phosphorothioate oligonucleotide metabolism. Antisense Nucleic Acids Drug Dev. 8, 35-42.

GODING, J.W., GROBBEN, B., and SLEGERS, H. (2003). Physiological and pathophysiological functions of the ecto-nucleotide pyrophosphatase/phosphodiesterase family. Biochim. Biophys. Acta 1638, 1-19.

GRAHAM, M.J., CROOKE, S.T., MONTEITH, D.K., COOPER, S.R., LEMONIDIS, K.M., STECKER, K.K., MARTIN, M.J., and CROOKE, R.M. (1998). In vivo distribution and metabolism of a phosphorothioate oligonucleotide within rat liver after intravenous administration. Pharmacol. Exp. Ther. 286, 447-458.

GROBBEN, B., CLAES, P., ROYMANS, D., ESMANS, E.L., VAN ONCELEN, H., and SLEGERS, H. (2000). Ecto-nu- cleotide pyrophosphatase modulates the purinoceptor-mediated signal transduction and is inhibited by purinoceptor antagonists. Br. J. Pharmacol. 130, 139-145.

GUGA, P., KOZIOLKIEWICZ, M., OKRUSZEK, A., and STEC, W.J. (1998). Oligo(nucleoside phosphorothioate)s. In: Applied Antisense Oligonucleotide Technology. C.A. Stein, and A. Krieg, eds. (Wiley Liss, Inc.), pp 23-50.

GUGA, P., DOMANSSKI, K., and STEC, W.J. (2001). Oxathiaphospholane approach to the synthesis of P-chiral, isotopomeric deoxy(ribonucleoside phosphorothioate)s and phosphates labeled with an oxygen isotope. Angew. Chem. Int. Ed. Engl. 40, 610-613.

HOSODA, N., HOSHIMO, S., KANDA Y., and KATADA T. (1999). Inhibition of phosphodiesterase/pyrophosphatase activity of PC-1 by its association with glycosaminoglycans. Eur. J. Biochem. 265, 763-770.

KOZIOLKIEWICZ, M., WÓJCIK, M., KOBYLAŃSKA, A., KARWOWSKI, B., RȨBOWSKA, B., GUGA, P., and STEC, W.J. (1997). Stability of stereoregular oligo(nucleoside phosphorothioate)s in human plasma: diastereoselectivity of plasma 3 '-exonuclease. Antisense Nucleic Acids Drug Dev. 7, 43-48.

KOZIOLKIEWICZ, M., GENDASZEWSKA, E., MASZEWSKA, M., STEIN, C.A., and STEC, W.J. (2001). The mononucleotide-dependent, nonantisense mechanism of action of phosphodiester and phosphorothioate oligonucleotides depends upon the activity of an ecto-5'-nucleotidase. Blood 98, 995-1002.

KOZIOLKIEWICZ, M., OWCZAREK, A., WÓJCIK, M., DOMAŃSKI, K., GUGA, P., and STEC, W.J. (2002). Retention of configuration in the action of human plasma 3 '-exonuclease on oligo(deoxynucleoside phosphorothioate). A new method for assignment of absolute configuration at phosphorus in isotopomeric deoxyadenosine $5^{\prime}-\mathrm{O}-\left[{ }^{18} \mathrm{O}\right]$-phosphorothioate. J. Am. Chem. Soc. 124, 4623-4627.

LEVIN, A.A. (1999). A review of issues in the pharmacokinetics and toxicology of phosphorothioate antisense oligonucleotides. Biochim. Biophys. Acta 1489, 69-84.

MISIURA, K., SZYMANOWICZ, D., and STEC, W.J. (2005). Synthesis of nucleoside $\alpha$-thiotriphosphates via an oxathiaphospholane approach. Org Lett. 7, 2217-2220.

MURRAY, A.W., and ATKINSON, M.R. (1968). Adenosine 5 '-phosphorothiate: a nucleotide analog that is a substrate, competitive inhibitor or regulator of some enzymes that interact with adenosine 5' -phosphate. Biochemistry 7, 40234029.

OKAWA, A., NAKAMURA, I., GOTO, S., MORIYA, H., NAKAMURA, Y., and IKEGAWA, S. (1998). Mutation in Npps in a mouse model of ossification of the posterior longitudinal ligament of the spine. Nature Genet. 19, 271-273.

PRITCHARD, A.E., KOWALSKI, D., and LASKOWSKI, M. (1977). An endonuclease activity of venom phosphodiesterase specific for single-stranded and superhelical DNA. J. Biol. Chem. 252, 8652-8659.

RUTSCH, F., RUF, N., VAINGANKAR, S. TOLIAT, M.R., SUK, A., HOHNE, W., SCHAUER, G., LEHMANN, M., ROSCIOLI, T., SCHNABEL, D., EPPLEN, J.T., KNISELY, A., SUPERTI-FURGA, A., McGILL, J., FILIPPONE, M., SINAIKO, A.R., VALANCE, H., HINRICHS, B., SMITH, 
W., FERRE, M., TERKELTAUB, R., and NURNBERG, P. (2003). Mutations in ENPP1 are associated with 'idiopathic' infantile arterial calcification. Nature Genet. 34, 379-381.

SALI, A., FAVALORO, J.M., TERKELTAUB, R., and GODING, J.W. (1999). Germline deletion of the nucleoside triphosphate pyrophosphohydrolase (NTPPH) plasma cell membrane glycoprotein (PC-1) produces abnormal calcification of periarticular tissues. In: Ecto-ATPases and Related Ectonucleotidases. L.Vanduffel, and R. Lemmens, eds. (Shaker Publishing, Maastricht, The Netherlands), pp 267-282.

STEC, W.J., UZNAŃSKI, B., WILK, A., HIRSCHBEIN, B.L., FEARON, K.L., and BERGOT, B.J. (1993). Bis(O,O-diisopropoxy phosphinothioyl)disulfide—a highly efficient sulfurizing reagent for cost-effective synthesis of oligo(nucleoside phosphorothioates)s. Tetrahedron Lett. 34, 5317-5320.

STEC, W.J., GRAJKOWSKI, A., KOBYLAŃSKA, A., KARWOWSKI, B., KOZIOLKIEWICZ, M., MISIURA, K., OKRUSZEK, A., WILK, A., GUGA, P., and BOCZKOWSKA, M. (1995). Diastereomers of nucleoside 3'O-2thio-1.3.2-oxathia(selena)phospholanes): Building blocks for stereocontrolled synthesis of oligo(nucleoside phosphorothioate)s. J. Am. Chem. Soc. 117, 12020-12029.

STEFAN, C., JANSEN, S., and BOLLEN, M. (2005). NPPtype ectophosphodiesterases: unity in diversity. Trends Biochem Sci. 30, 542-550.

STOYNOV, S.S., BAKALOVA, A.T., DIMOV, S.I., MITKOVA, A.V., and DOLAPCHIEV, L.B. (1997). Singlestranded-specific DNase activity is an inherent property of the $140-\mathrm{kDa}$ protein of the snake venom exonuclease. FEBS Lett. 409, 151-154.

TERKELTAUB, R.A. (2001). Inorganic pyrophosphatase generation and disposition in pathophysiology. Am. J. Physiol. Cell. Physiol. 281, C1-C11.

TOKUMURA, A., MAJIMA, E., KARIYA, Y., TOMINAGA, K., KOGURE, K., YASUDA, K., and FUKUZAWA, K. (2002). Identification of human plasma lysophospholipase D, a lysophosphatidic acid-producing enzyme, as autotaxin, a multifunctional phosphodiesterase. J. Biol. Chem. 277, 39436-39442.

UMEZU-GOTO, M., KISHI, Y., TAIRA, A., HAMA, K., DOHMAE, N., TAKIO, K., YAMORI, T., MILLS, G.B., INOUE, K., AOKI, J. and ARAI, H. (2002). Autotaxin has lysophosphatidic D activity leading to tumor cell growth and motility by lysophosphatidic acid production. J. Cell. Biol. 158, 227-233.
VAERMAN, J.L., MOUREAU, P., DELDIME, F., LEWALLE, P., LAMMINEUR, C., MORSCHHAUSER, F., and MARTIAT, P. (1997). Antisense oligodeoxyribonucleotides suppress hematologic cell growth through stepwise release of deoxyribonucleotides. Blood 90, 331-339.

VOLLMAYER, P., CLAIR, T., GODING, J.W., SANO, K., SERVOS, J., and ZIMMERMANN, H. (2003). Hydrolysis of diadenosine polyphosphates by nucleotide pyrophosphatases/phosphodiesterases. Eur J. Biochem. 270, 29712978.

WICKSTROM, E. (1986). Oligodeoxynucleotide stability in subcellular extracts and culture media. J. Biochem. Biophys. Methods 13, 97-102.

YEGUTKIN, G.G., HENTTINEN, T., SAMBURSKI, S.S, SPYCHALA, J., and JALKANEN S. (2002). The evidence for two opposite ATP-generating and ATP-consuming extracellular pathways on endothelial and lymphoid cells. Biochem. J. 367, 121-128.

ZALATAN, J.G., FERN, T.G., BRUNGER, A.T., and HERSCHLAG, D. (2006). Structural and functional comparisons of nucleotide pyrophosphatase/phosphodiesterase and alkaline phosphatase: implications for mechanism and evolution. Biochemistry 45, 9788-9803.

ZON, G., and STEC, W.J. (1991). Phosphorothioate oligonucleotides. In: Oligonucleotides and Analogues: A Practical Approach. F. Eckstein, ed. (IRL Press, Oxford), pp 87-108.

$$
\begin{array}{r}
\text { Address reprint requests to: } \\
\text { Dr. Maria Koziołkiewicz } \\
\text { Department of Bioorganic Chemistry } \\
\text { Centre of Molecular and Macromolecular Studies } \\
\text { Polish Academy of Sciences } \\
\text { Sienkiewicza 112 } \\
90-363 \text { Lódź } \\
\text { Department of Technical Biochemistry } \\
\text { Technical University of Lódź } \\
\text { Stefanowskiego 4/10 } \\
90-924 \text { Lódź. Poland } \\
\end{array}
$$

Received April 6, 2006; accepted in revised form October 31, 2006. 